\title{
ARTIKELEN
}

\section{Zelfrealisatie in onderzoek en methode}

\author{
Lisanne Groen
}

\section{$1 \quad$ Inleiding}

Toen ik in 2007 het voorstel schreef voor het onderzoek naar het zelfrealisatierecht waaraan ik op dit moment de laatste hand leg, was de discussie over de aard van de rechtswetenschap, die onder andere in het Nederlands Juristenblad werd gevoerd, in volle gang. Ik heb dit debat met interesse gevolgd en de voortschrijdende inzichten die dat mij heeft opgeleverd, gebruikt voor het aanscherpen van mijn probleemstelling en voor het formuleren van toetsingscriteria ten behoeve van de beantwoording van die probleemstelling. Dit artikel bevat een beknopt verslag van de keuzes die ik in de loop van het proces op deze gebieden heb gemaakt en de overwegingen die daaraan ten grondslag hebben gelegen. Andere methodologische aspecten van het onderzoek - bijvoorbeeld de methode van interpretatie die ik hanteer, de verschillende bronnen die ik gebruik en de manier waarop ik die verantwoord - zullen in dit artikel niet aan de orde komen. ${ }^{1}$

In de eerste plaats zal ik kort uiteenzetten waarover mijn onderzoek gaat (par. 2). Paragraaf 3 zal vervolgens handelen over de totstandkoming van mijn probleemstelling en de toetsingscriteria aan de hand waarvan ik de probleemstelling wil(de) beantwoorden. Ik zal beschrijven hoe ik in eerste instantie een normatieve probleemstelling formuleerde (par. 3.1), maar worstelde met de criteria om op de gestelde vraag een antwoord te kunnen formuleren: verschillende criteria die in eerste instantie geschikt leken, bleek ik bij nader inzien niet te kunnen operationaliseren. Als oplossing voor dit probleem schrapte ik het normatieve element uit mijn probleemstelling (par. 3.2), maar ook dat leidde niet tot een bevredigend resultaat: ik bleek toch écht ook normatieve beweringen over mijn onderzoeksonderwerp te willen doen. De derde en laatste aanpassing van mijn probleemstelling heeft er dan ook toe geleid dat het normatieve element erin is teruggekeerd, maar dat de criteria aan de hand waarvan ik de vraag wil beantwoorden wél operationeel zijn (par. 3.3).

Paragraaf 4 vormt de afsluiting waarin ik ook mijn positie in het debat kort weergeef.

1 Zie voor een overzicht van (de verantwoording van) methodologische aspecten aan juridische dissertaties Tijssen 2009. 


\section{Zelfrealisatie in onderzoek}

Mijn dissertatieonderzoek gaat over het zelfrealisatierecht. Over de inhoud van dit recht bestaat nogal wat verwarring, al wordt algemeen aangenomen dat het op enigerlei wijze samenhangt met het eigendomsrecht. ${ }^{2}$ Het zelfrealisatierecht koppelt aan grondeigendom een ontwikkelingsrecht: aan de particuliere eigenaar van een perceel komt in principe het recht toe de door de gemeenteraad vastgestelde bestemming voor dat perceel zelf te realiseren. Wanneer een particuliere grondeigenaar overgaat tot het realiseren van de nieuwe bestemming op zijn grond, zal de overheid - en in mijn onderzoek betreft het dan meestal de gemeentelijke overheid - doorgaans een zekere mate van invloed op die realisering willen uitoefenen. Verschillende instrumenten die in verschillende wetten zijn neergelegd stellen haar hiertoe in staat. De toepassing daarvan kan er evenwel toe leiden dat spanning ontstaat tussen de belangen van de grondeigenaar en die van de overheid.

\subsection{Het zelfrealisatierecht en wetgeving}

Van de oorzaak van de verwarring omtrent de inhoud van het zelfrealisatierecht, kreeg ik tijdens mijn eerste, verkennende onderzoek een indruk. De term 'zelfrealisatie' komt in wetgeving niet voor, maar speelt uitdrukkelijk een rol in de jurisprudentie bij de Onteigeningswet (hierna: 'Ow') en de Wet voorkeursrecht gemeenten (hierna: 'Wvg'). Bij de totstandkoming van de Grondexploitatiewet (hierna: 'Grex') is realisering van bestemmingen door private partijen een van de uitgangspunten geweest. De drie wetten bevatten instrumenten waarmee gemeenten grondbeleid kunnen voeren. Daarnaast speelt het zelfrealisatierecht een rol onder de Aanbestedingsrichtlijn.

In de jurisprudentie bij de Wvg legt de rechter het zelfrealisatierecht anders uit dan in de jurisprudentie bij de Ow. De Wvg maakt vestiging van een voorkeursrecht door $\mathrm{B}$ en $\mathrm{W}$ op een stuk grond van een private grondeigenaar mogelijk. Wanneer dat is gebeurd en de eigenaar wil zijn grond verkopen, moet hij deze eerst aan de gemeente aanbieden. Vestiging van een voorkeursrecht brengt géén verkoopplicht met zich: als de eigenaar de grond zélf wil houden, staat de vestiging van het voorkeursrecht door de gemeente daaraan niet in de weg. Onder de Wvg speelt het zelfrealisatierecht een rol bij de toepassing van artikel 26: op grond van dit artikel kan de gemeente de nietigheid inroepen van rechtshandelingen die de grondeigenaar heeft verricht, en die volgens de gemeente de 'kennelijke strekking' hebben afbreuk te doen aan het voorkeursrecht. Meestal gaat het om samenwerkingsovereenkomsten die de grondeigenaar met derden - niet zijnde de gemeente - heeft gesloten. Daarbij wordt dan niet de grond zelf, maar wel (een deel van) de beschikkingsmacht óver de grond aan die derde overgedragen. Ontstaat hierover een conflict - de gemeente roept artikel $26 \mathrm{Wvg}$ in, de grondeigenaar stelt dat hij door middel van de samenwerking zélf de bestemming op zijn grond wil realiseren - dan beziet de rechter wie voor de realisering van de

2 Zie o.a. Sluysmans \& Bronneman 2006, p. 288; Bregman \& Lubach 2000, p. 43 e.v.; Kamerstukken II 2000/01, 27 581, nr. 2, p. 6-7 e.v. 
bestemming het risico draagt. Is dat de grondeigenaar, dan neemt de rechter aan dat van zelfrealisatie sprake is. Is dat de derde met wie de samenwerkingsovereenkomst is gesloten, dan oordeelt de rechter dat de grondeigenaar een rechtshandeling heeft verricht waarmee aan het voorkeursrecht van de gemeente afbreuk is gedaan.

Onder de Ow speelt het recht een rol als in het belang van de ruimtelijke ontwikkeling - bijvoorbeeld omdat een nieuwe bestemming op een particulier stuk grond moet worden gerealiseerd - een onteigeningsbesluit wordt genomen. Onteigening moet volgens artikel 79 noodzakelijk zijn; het is tenslotte een bijzonder ingrijpend middel dat slechts als 'ultimum remedium' mag worden gebruikt. ${ }^{3}$ Wanneer de grondeigenaar zich tegen het onteigeningsbesluit verweert door te stellen dat onteigening niet noodzakelijk is omdat hij zélf in staat is de nieuwe bestemming op zijn grond te realiseren, toetst de rechter of hij hiertoe 'bereid en in staat' is. Hiervoor is níet doorslaggevend of de eigenaar voor eigen rekening en risico realiseert - samenwerkingsovereenkomsten die onder de Wvg zouden worden nietigverklaard, zijn onder de Ow dus in beginsel toegestaan - maar of hij zich aan de door de gemeente vastgestelde 'vorm van planuitvoering', die bijvoorbeeld kan zien op fasering van de bouw, kan houden.

Eén van de uitgangspunten bij de totstandkoming van de Grex was - als gezegd particuliere grondexploitatie (dus realisering van bestemmingen door private partijen). De wet biedt aan gemeenten instrumenten om, in geval van particuliere grondexploitatie, door haar gemaakte kosten voor voorzieningen van openbaar nut (bijvoorbeeld voor de aanleg van riolering in een woongebied) op die particuliere exploitanten te kunnen verhalen en locatie-eisen te stellen (bijvoorbeeld ten aanzien van de typen huizen die in dat woongebied moeten worden gebouwd). Hoe de Grex de reikwijdte van het zelfrealisatierecht zal beïnvloeden is onduidelijk, maar het ligt voor de hand dat gemeenten de realisering van bestemmingen door particulieren als minder problematisch zullen ervaren. Vóórdat de Grex in werking trad, was het verhalen van kosten voor gemeenten bijzonder lastig en bestond voor het stellen van locatie-eisen helemaal geen wettelijk instrument. Dit waren belangrijke redenen voor gemeenten om de wens van een private grondeigenaar zélf tot realisering van een nieuwe bestemming over te gaan, niet steeds toe te juichen. De inwerkingtreding van de Grex zou daarin verandering kunnen brengen.

\subsection{Factoren die het zelfrealisatierecht beïnvloeden}

Aan het zelfrealisatierecht wordt dus - afhankelijk van de context waarin het recht een rol speelt - op verschillende manieren invulling gegeven. Op basis van mijn eerste, verkennende onderzoek kwam ik tot de conclusie dat een aantal factoren van groot belang is voor de uitleg van het recht in een bepaalde, concrete situatie.

3 Sinds de inwerkingtreding van de Crisis- en herstelwet (Stb. 2010, 136) staat dit 'noodzaakvereiste' niet meer met zoveel woorden in de vierde titel vermeld. De voorwaarde geldt - mede in het licht van de vereisten in de Grondwet en het EVRM - echter nog wel. Kamerstukken II 2009/10, 32 217, nr. 3, p. 35. 
De eerste belangrijke factor wordt gevormd door de uiteenlopende belangen van de bij het recht betrokken partijen. De belangen van de overheid - ter behartiging waarvan de instrumenten in de hiervoor genoemde, nationale wetten zijn geformuleerd - zijn gericht op de 'bewoonbaarheid van het land' (vgl. artikel 21 Grondwet): de overheid heeft als taak een deugdelijk ruimtelijkeordeningsbeleid te voeren. De belangen van de particuliere grondeigenaren vloeien voort uit het in artikel 5:1 BW en artikel 1 Eerste Protocol bij het EVRM neergelegde eigendomsrecht, en zijn gericht op het ongestoorde genot daarvan.

Instrumenten die in het kader van een goed ruimtelijkeordeningsbeleid door de wetgever worden ontworpen, kunnen ingrijpen in het eigendomsrecht van particuliere grondeigenaren. In het meest vergaande geval kan hun eigendomsrecht helemaal overgaan op de overheid, maar ook minder vergaande bevoegdheden dan die tot onteigening zijn dikwijls van invloed op het recht van de eigenaar over zijn eigendom te beschikken, zijn eigendom te gebruiken of er de vruchten van te trekken. In concrete gevallen moet steeds een afweging worden gemaakt tussen het publieke belang dat de overheid probeert te dienen en het individuele eigendomsrecht van de private grondeigenaar.

De tweede factor die van belang is voor de uitleg van het zelfrealisatierecht, heeft te maken met de omstandigheid dat het aantal particuliere grondeigenaren sinds een aantal decennia toeneemt. ${ }^{4}$ Dit zorgt ervoor dat samenwerking tussen gemeenten en grondeigenaren een steeds grotere rol is gaan spelen, en daardoor ook het zelfrealisatierecht. Vóórdat de Grex op 1 juli 2008 in werking trad, kwam deze samenwerking niet steeds zonder slag of stoot tot stand. Pogingen tot samenwerking strandden bijvoorbeeld als de gemeente de door haar gemaakte kosten niet op de grondeigenaren kon verhalen of als geen overeenstemming kon worden bereikt over hoe de nieuwe bestemming er precies uit moest komen te zien. Wanneer samenwerking tussen gemeente en grondeigenaar niet tot stand kwam wegens (vermeende) onverenigbaarheid van belangen van beide partijen en zij allebei wilden overgaan tot realisering van de bestemming, ontstond een conflict: de gemeente probeerde de grond in eigendom te verkrijgen door middel van het instrumentarium van de Wvg en de Ow; de grondeigenaar probeerde dit af te wenden door middel van een zelfrealisatieverweer.

Zoals ik heb aangegeven, beoogt de Grex hiervoor een oplossing te bieden. Niet alleen leiden de nieuwe regels van de Grex tot een nieuwe uitleg van het zelfrealisatierecht; ook beïnvloeden zij mogelijkerwijs de uitleg van het recht zoals die onder de Wvg en de Ow bestaat.

In de derde plaats zijn de verschillende doelstellingen van de wetten waaronder het zelfrealisatierecht een rol speelt, van belang voor de uitleg van het recht. Dat het recht onder de verschillende wetten een verschillende invulling heeft, vloeit hieruit onder andere voort: waar de $\mathrm{Ow}$ is bedoeld om ontneming van particuliere eigendom mogelijk te maken in het belang van - onder andere - volkshuisvesting en ruimtelijke ontwikkeling, is met de Wvg beoogd om de uitoefening van een voorkeursrecht door gemeenten mogelijk te maken, zodat zij makkelijker grond kunnen kopen en bij de realisering van bestemmingen een 'regisserende rol' kun- 
nen vervullen. Met de Grex wilde de wetgever in de eerste plaats instrumenten creëren waardoor gemeenten bij particuliere grondexploitatie gemakkelijker kosten zouden kunnen verhalen en eisen aan de realisering van de bestemming zouden kunnen stellen, en met de Aanbestedingsrichtlijn wilde men - op Europees niveau - transparante en doelmatige marktwerking bevorderen.

De verschillende doelstellingen brengen met zich dat de instrumenten die aan de overheid door middel van de wetten ter beschikking zijn gesteld, steeds op een ander moment en met een andere reden worden ingezet. Ook de rechterlijke toetsing van een zelfrealisatieverweer onder de Ow en onder de Grex verschilt. De wijze van toetsing onder de Grex is nog niet volledig uitgekristalliseerd.

Mijn eerste, verkennende onderzoek leidde dus tot de conclusie dat aan het zelfrealisatierecht niet steeds op dezelfde manier invulling wordt gegeven. Daarnaast concludeerde ik dat in ieder geval drie factoren van invloed zijn op de uitleg in een concreet geval. Met de doelstelling een bijdrage te leveren aan het terugdringen van de verwarring die over de inhoud van het zelfrealisatierecht bestaat - en die voor mij een reden was geweest me in het onderwerp te gaan verdiepen - besloot ik dat de probleemstelling van mijn onderzoek gericht moest zijn op het bepalen van de reikwijdte van het zelfrealisatierecht en, parallel daaraan, op de mogelijke beperkingen die door de overheid op het recht kunnen worden aangebracht.

\section{Zelfrealisatie in methode}

Zoals ik in de inleiding al aangaf: het volgen van het debat over de aard van de rechtswetenschap, heeft me doen inzien dat sommige van de onderzoeksplannen die ik aanvankelijk had, niet haalbaar waren. Ook heeft het me geholpen mijn probleemstelling en de noodzakelijke toetsingscriteria voor de beantwoording daarvan scherper te formuleren. Ik zal in deze paragraaf voorbeelden beschrijven van de gevolgen van dat voortschrijdend inzicht.

\subsection{Probleemstelling I}

In het oorspronkelijke onderzoeksvoorstel luidde mijn probleemstelling: wat is de reikwijdte van het zelfrealisatierecht en op welke wijze mag de overheid het beperken? Terecht merkte een van de referenten naar aanleiding van mijn toelichting bij deze onderzoeksvraag op dat het hier een normatieve probleemstelling betrof: ik wilde niet alleen onderzoeken wat de invulling van het zelfrealisatierecht is, maar ook wat deze invulling idealiter zou moeten zijn. Een echt juridische vraag dus. ${ }^{5}$ Maar wel buitengewoon lastig te beantwoorden: om aannemelijk te maken dat een bepaalde invulling van het recht beter zou zijn dan een andere invulling, zou ik goed moeten beargumenteren waarom dan. De logische vervolgvraag was dan ook: aan de hand van welke criteria zou ik gaan beoordelen of de overheid het zelfrealisatierecht al dan niet zou mogen beperken? Verschillende mogelijkheden passeerden de revue. Ik zal ze hier kort toelichten.

5 Zie over de normativiteit van de rechtswetenschap o.a. Stolker 2003; Van Manen 2008; De Bruin 2009. 


\subsubsection{Politiek-bestuurlijke achtergronden}

Over de vraag naar de toetsingscriteria had ik bij het schrijven van het voorstel wel nagedacht, maar ik was nog niet tot een bevredigende oplossing gekomen. Ik had aangegeven dat de spanning tussen de belangen van de grondeigenaar en die van de overheid een leidende rol vervullen bij de vraag naar de invulling van het zelfrealisatierecht. Voor de beantwoording van de vraag naar de reikwijdte van het zelfrealisatierecht wilde ik de afweging van die belangen dus op een of andere manier als uitgangspunt nemen. Maar hoe?

In eerste instantie vatte ik het plan op de spanning tussen de belangen van grondeigenaren en die van de overheid te plaatsen in een soort politiek-bestuurlijk kader. Visies op eigendom en op de meest ideale inrichting van het land hadden immers een sterk politiek-bestuurlijke lading, ${ }^{6}$ en het leek me daarom een goed idee daarbij aansluiting te zoeken.

Bij nadere beschouwing deed zich echter een probleem voor. Stel: ik zou ervan uitgaan dat politiek-bestuurlijke opvattingen noodzakelijkerwijs van invloed zijn op ideeën over eigendom en de mate waarin de overheid die eigendom in het algemeen belang mag beperken (dus: op de vraag in welke gevallen en in welke mate zelfrealisatie al dan niet is toegestaan). Dan zou daaruit volgen dat die opvattingen tevens van grote invloed zijn op de visie die iemand heeft op de ideale taakverdeling tussen overheid en burgers of private organisaties: vanuit de ene opvatting is het immers eerder gerechtvaardigd een inbreuk te maken op het eigendomsrecht van een burger (of een private organisatie) dan vanuit een andere opvatting. Deze constatering leidde mijns inziens tot complicaties: toetsing aan één politiek-bestuurlijke opvatting (namelijk: de mijne) was misschien weliswaar doeltreffend, maar naar alle waarschijnlijkheid helaas niet wetenschappelijk. Ik zou steeds naar mijn eigen opvattingen toe schrijven, waardoor mijn proefschrift zou verworden tot een soort politiek pleidooi. Dit zou ik kunnen ondervangen door het zelfrealisatierecht te belichten vanuit meerdere politiek-bestuurlijke opvattingen. In dat geval zou ik echter geen antwoord meer kunnen geven op de vraag waar het me nu juist om ging: in welke richting kan de invulling van het zelfrealisatierecht zich het beste ontwikkelen? Die vraag kan immers slechts worden beantwoord vanuit de visie die je aanhangt.

De enige manier waarop ik die vraag wél zou kunnen beantwoorden - naast het kiezen voor het vertegenwoordigen van een bepaalde visie, maar die mogelijkheid had ik al verworpen - zou aan de hand van een bepaald 'visie-overstijgend' beginsel of uitgangspunt zijn. Daarnaar ging ik op zoek.

\subsubsection{Democratisch-rechtsstatelijke beginselen}

Vanuit het onderzoeksprogramma waarbinnen ik het voorgenomen onderzoek wilde uitvoeren, werd toetsing aan democratisch-rechtsstatelijke beginselen voorgesteld. ${ }^{7}$ Ik besloot me nader in die beginselen te verdiepen.

6 Tweemaal is een conflict over grondpolitiek zelfs uitgemond in een kabinetscrisis, vgl. De Vries 1989. Zie over het 'politieke' karakter van het grondbeleid ook Van Zundert 1980.

$7 \quad$ Vgl. Van Ommeren \& Zijlstra 2003. 
Dat leidde meteen al tot een verontrustende constatering: over 'de' beginselen van de democratische rechtsstaat bestond - in ieder geval op het eerste gezicht minder overeenstemming dan ik van tevoren vermoedde. Ter illustratie: Scheltema (1989) noemt in zijn bekende artikel het rechtszekerheidsbeginsel, het gelijkheidsbeginsel, het democratiebeginsel en het beginsel van een dienende overheid. Burkens e.a. (2006) noemen het legaliteitsbeginsel, de verdeling van machten, grondrechten en rechterlijke controle als uitgangspunten van de klassiek-liberale rechtsstaatidee. Democratie kenschetsen zij niet zozeer als een beginsel, maar eerder als een wijze van besluitvorming. Verder beschrijven zij de ontwikkeling van de klassiek-liberale rechtsstaat naar de sociale rechtsstaat, die wordt gekenmerkt door beschermende, stimulerende en herverdelende overheidsmaatregelen in de sociaaleconomische sfeer. Van Ommeren (2003) maakt onderscheid tussen waarden die een staat moet realiseren om als rechtsstaat te kunnen worden aangemerkt (vrijheid, rechtszekerheid en rechtsgelijkheid) en formuleert vervolgens instrumenten met behulp waarvan dit kan geschieden (het legaliteitsbeginsel, de grondrechten, de machtsverdeling en de rechterlijke controle). Dit alles vindt idealiter plaats via democratische besluitvorming, die gericht is op soevereiniteit en medezeggenschap. Eenzelfde soort benadering kiest Zijlstra, die differentieert tussen centrale beginselen van de democratische rechtsstaat (zeggenschap, vrijheid, rechtszekerheid, rechtsgelijkheid en sociale rechtvaardigheid ${ }^{8}$ ) en nadere beginselen, die dienend zijn aan de centrale beginselen en daarvan een uitwerking vormen (bijvoorbeeld politieke verantwoordelijkheid, rechterlijke controle en de verdeling van machten). Dat de nadere beginselen dienend zijn, betekent dat ze moeten worden vervangen als ze niet afdoende leiden tot de verwezenlijking van de centrale beginselen. ${ }^{9}$

Later bleken de onderling afwijkende indelingen en definities van de beginselen minder verontrustend dan ik in eerste instantie dacht: de verschillende auteurs waren het wel min of meer eens over het doel dat met de beginselen moest worden gediend. Zijlstra verwoordt het kernachtig: de idee van de democratische rechtsstaat vormt een uitdrukking van de gebondenheid van de overheid aan het recht en de beginselen normeren het handelen van de overheid. ${ }^{10}$

Goed. Maar wat moest ik daar onderzoekstechnisch mee? Het uitgangspunt dat Nederland niet alleen feitelijk, maar ook normatief als democratische rechtsstaat moet worden gekwalificeerd onderschreef ik wel, en dus ook het standpunt dat democratisch-rechtsstatelijke beginselen leidend moeten zijn bij de inrichting van de staat en het formuleren van instrumenten die daartoe behulpzaam kunnen zijn. Maar hoe kon ik die notie in mijn onderzoek gestalte geven? Ik kon toch moeilijk alle ruimtelijke doelstellingen van de overheid en de ter verwezenlijking daarvan door de wetgever gecreëerde instrumenten langs de 'meetlat' van de diverse beginselen leggen - de inbreuk die in concrete gevallen door die instru-

8 Zijlstra ziet de 'positieve staatstaak' - het verwezenlijken van sociale rechtvaardigheid - als onderdeel van het democratisch-rechtsstatelijk schema, in tegenstelling tot bijv. Burkens e.a. 2006 en Kortmann 2005, p. 66. Vgl. ook Zijlstra 2010, p. 39-40.

9 Zijlstra 2010, p. 28-29. Zijlstra verwijst naar het hiervoor ook aangehaalde artikel van Scheltema, die de dienende beginselen als ‘eisen’ aanmerkt (Scheltema 1989, p. 15). 
menten op het eigendomsrecht van burgers werd gemaakt, daarbij in aanmerking genomen? Hoe moest ik dat allemaal afwegen?

Een mogelijkheid om de beginselen van de democratische rechtsstaat als toetsingskader te gebruiken op een concrete manier, kwam bij mij op na het lezen van een preadvies van - opnieuw - Zijlstra (2008). In dat preadvies stelt hij dat de idee van de democratische rechtsstaat met zich brengt dat de overheid zo min mogelijk mag ingrijpen in de rechten en vrijheden van burgers. Pas als burgers en private organisaties een bepaald publiek belang ${ }^{11}$ niet afdoende kunnen waarborgen - zelfs niet als zij daarbij, bijvoorbeeld door middel van subsidie, door de overheid worden geholpen - dient de overheid in te grijpen. Bij het behartigen van publieke belangen geldt dus principieel een voorkeur voor het particulier initiatief, zelfs als die belangen grondwettelijk of verdragsrechtelijk zijn bepaald - zoals het geval is met de belangen die samenhangen met de "bewoonbaarheid van het land' ex artikel $21 \mathrm{Gw} .{ }^{12}$ Dit leek me een werkbare veronderstelling: vertaald naar mijn onderzoeksvraag zou ik ervan uit kunnen gaan dat publieke belangen als een goede ruimtelijke ordening en adequate volkshuisvesting in beginsel door burgers of private organisaties moesten worden gerealiseerd - zelfrealisatie als uitgangspunt dus. Pas als zij dat niet afdoende zouden kunnen, zou de overheid mogen ingrijpen.

Voor invulling van de term 'afdoende' zocht ik aansluiting bij Scheltema, die in zijn hiervoor al aangehaalde artikel stelt dat uit het beginsel van de dienende overheid de eis voortvloeit dat de overheid haar werkzaamheden, gericht op het dienen van het belang van de burgers, zo doeltreffend en efficiënt mogelijk moet verrichten. ${ }^{13}$ Áls de overheid optreedt, dient dat volgens Scheltema dus zo doeltreffend en efficiënt mogelijk te gebeuren. Wanneer een burger of een private organisatie tot behartiging van een publiek belang zou overgaan, leek me dat ook dat 'doeltreffend en efficiënt' zou moeten gebeuren - met die kanttekening dat deze begrippen dan minder strikt hoefden te worden afgebakend; de beginselen van de democratische rechtsstaat stellen immers eisen aan de overheid, en niet aan burgers of hun organisaties.

Minder strikt dus. Maar dan nog: hoe kon ik de begrippen 'doelmatig en efficiënt' zinvol invullen in het licht van mijn probleemstelling? Wat zouden een 'doelmatige en efficiënte' realisering van bestemmingen (en invulling van het zelfrealisatierecht) inhouden? Zo snel mogelijk? Zo goedkoop mogelijk? Zo snel én zo goedkoop mogelijk? Ook nu deden zich problemen voor als ik 'doelmatigheid' en 'efficiëntie' zou moeten waarderen. Ik zou dan ofwel buiten mijn eigen onderzoeksvaardigheden moeten treden, want hoe zou ik aan de hand van mijn juridische tools kunnen vaststellen dat realisering van een bestemming bij een bepaalde invulling van het zelfrealisatierecht sneller en goedkoper zou zijn dan bij een andere invulling van het recht? Ofwel ik zou - tamelijk ongefundeerd en

11 In een rapport van de Wetenschappelijke Raad voor het Regeringsbeleid wordt een 'publiek belang' gedefinieerd als een belang waarvan de behartiging een doelstelling van de overheid is. WRR 2000, nr. 56, p. 21.

12 Zijlstra 2008, p. 77.

13 Scheltema 1989, p. 21. 
voornamelijk op basis van gezond verstand - zelf een bepaalde invulling aan beide begrippen moeten geven, en dan vreesde ik dat bij het verschijnen van mijn proefschrift eerder zou worden gediscussieerd over de invulling van de begrippen dan over de reikwijdte van het zelfrealisatierecht. Ofwel ik zou opnieuw verzanden in politiek geladen definities - en dat wilde ik nu juist voorkomen.

\subsection{Probleemstelling II}

Ik besloot een nieuwe probleemstelling te formuleren. Een probleemstelling zonder normatieve component, op grond waarvan ik gewoon onderzoek zou kunnen doen naar het positieve recht: wat is de reikwijdte van het zelfrealisatierecht en op welke wijze beperkt de overheid het?

Om deze vraag te beantwoorden, begon ik met het in kaart brengen van de wetsgeschiedenis en de jurisprudentie bij de Ow, Wvg en Grex. Op grond van welke argumenten werden beperkingen op het zelfrealisatierecht aangebracht, en wat waren steeds de omstandigheden van het concrete geval? Kon een verklaring voor de verschillende benaderingen van de rechter uitsluitend voortvloeien uit de verschillende doelstellingen van de wetten? En wat was nu precies de doelstelling van de Grex, waarin het zelfrealisatierecht als uitgangspunt werd gehanteerd?

Allemaal bijzonder relevante vragen. Er was alleen toch weer iets wat knaagde: als een van de wetten zou worden gewijzigd of als de overheid met haar ruimtelijkeordeningsbeleid ineens een andere richting zou inslaan, zou mijn proefschrift onmiddellijk gedateerd zijn. De kans dat zoiets kort na verschijning al zou gebeuren, achtte ik - gezien de beweging die het rechtsgebied kenmerkt - vrij aanzienlijk. En daarbij: juridische probleemstellingen mochten toch juist bij uitstek normatief zijn, aangezien de rechtswetenschap ook bij uitstek een normatieve wetenschap is ? $^{14}$

\subsubsection{Rechtswetenschap als empirische wetenschap}

Wanneer ik echter opnieuw een normatieve probleemstelling zou formuleren, moest ik - in tegenstelling tot mijn eerdere pogingen - het onderzoek natuurlijk wel zó opzetten dat ik de vraag die ik zou stellen, ook daadwerkelijk zou kunnen beantwoorden. Daarvoor had ik duidelijker toetsingscriteria nodig. Uit een artikel van De Geest (2004) leerde ik dat ik met dat inzicht inderdaad op het goede spoor zat: hij stelt dat de rechtswetenschap een voorbeeld zou moeten nemen aan empirische wetenschappen, met name waar het methode en toetsingscriteria betreft. Om optimaal recht te kunnen bepalen - en dus uitspraken te kunnen doen over de richting waarin het recht zich zou moeten ontwikkelen - dienen volgens De Geest eerst doelstellingen te worden geformuleerd. Dit gebeurt buiten de wetenschap om, aangezien deze niet kan bepalen wat goed of slecht is. Zij kan wél bepalen welke maatregelen de doelstellingen het best verwezenlijken. De Geest geeft daarbij aan dat de ultieme doelstelling van het recht zijns inziens utilitaristisch is: het gaat altijd om het maximaliseren van geluk in de samenleving. Voor de meeste takken van het recht kan deze doelstelling worden geconcretiseerd in kostenminimalisatie. Voor hen die géén utilitaristische basisnorm aanvaarden, is van 
belang dat zij op basis van de sociaalwetenschappelijke methodologie een toetsbaar equivalent formuleren. Ook dan zul je echter - zo stelt De Geest - steeds bij de economische wetenschap terechtkomen. En daarmee was ik dus weer terug bij af: in de sociaalwetenschappelijke en economische onderzoeksmethoden was ik helaas niet ingevoerd. Daarbij stond me aan de opvatting van De Geest tegen dat werkelijk alles op geld waardeerbaar zou zijn - een standpunt dat ik, ook al had ik de begrippen 'doelmatig' en 'efficiënt' óók met kostenminimalisatie in verband willen brengen, toch stiekem beschouw als een devaluatie van de rechtswetenschap.

\subsubsection{Rechtswetenschap als hermeneutische wetenschap}

Meer aansluiting vond ik bij Westerman en Wissink (2008) en Taekema en Van Klink (2009). Het eerste duo betoogt dat juridisch onderzoekers zich vooral bezighouden met de interpretatie van teksten. Rechtswetenschappelijk onderzoek lijkt - zo betogen zij - op dit punt sterk op het onderzoek van literatuurwetenschappers, ideeënhistorici en Bijbeluitleggers: de onderzoekers zijn op zoek naar de betekenis van een tekst, en moeten hierbij rekening houden met 1) de opsteller van de tekst en diens bedoelingen; 2) de logica van de tekst zelf; en 3) de betekenis die de tekst voor ons heeft. In dat opzicht onderscheiden zij zich van empirische wetenschappers, die vooral rekening hebben te houden met de feiten die uit een experiment of een statistisch onderzoek naar voren komen en met de eigen theorie en de hieruit voortvloeiende hypothese.

De vergelijking tussen rechtswetenschappers en andere wetenschappers die zich met interpretatie bezighouden, gaat echter niet helemaal op, zo stellen zij vervolgens. Een belangrijk verschil tussen een rechtswetenschapper en bijvoorbeeld een literatuurwetenschapper is dat voor de eerste hetgeen onderwerp van onderzoek is, tegelijkertijd ook fungeert als theoretisch kader: object van onderzoek en theoretisch perspectief vallen samen. Rechtswetenschappers pogen nieuwe ontwikkelingen te doen aansluiten bij het bestaande rechtssysteem door gebruik te maken van begrippen uit datzelfde rechtssysteem. Westerman en Wissink stellen dat eisen van consistentie en coherentie in interpretatie daarom voor rechtswetenschappers nog zwaarder wegen dan voor andere interpretatieve wetenschappers. Daarnaast stellen zij dat rechtswetenschappers niet kunnen kiezen welke methode ze hanteren, zoals sociaal wetenschappers die, afhankelijk van hun probleemstelling, kunnen kiezen voor bijvoorbeeld een kwalitatieve of een kwantitatieve aanpak. De juridische methode bestaat noodzakelijkerwijs uit het verzamelen en interpreteren van relevante wetgeving en jurisprudentie, historisch onderzoek naar de ontwikkeling daarvan, het beoordelen van de gehanteerde argumenten en zelf argumenteren. Ook niet-rechtswetenschappelijke perspectieven kunnen hierin worden betrokken.

Deze laatste overweging wordt door Taekema en Van Klink onderschreven. Zij stellen dat rechtswetenschappers gebruik kunnen maken van een hulpwetenschap als zij een probleem hebben geformuleerd dat niet geheel met juridische methoden kan worden opgelost. In hun artikel stellen ze vervolgens verschillende gradaties van interdisciplinair onderzoek aan de orde: de 'lichtste' vorm is het heuristisch gebruik van een andere discipline (de andere discipline wordt dan 
slechts als inspiratiebron gebruikt); de 'zwaarste' vorm is interdisciplinair onderzoek, dat zowel perspectivisch (de onderzoeksvraag wordt vanuit verschillende disciplines benaderd, maar in het onderzoek worden de methoden van elk van de disciplines gebruikt) als geïntegreerd (een combinatie van methoden uit beide disciplines leidt tot een nieuwe benadering) kan geschieden. Uiteraard geldt dat hoe 'interdisciplinairder' het onderzoek is vormgegeven, hoe meer wordt gevraagd van de onderzoeksvaardigheden van de onderzoeker.

Op basis van deze uitgangspunten moest het me toch lukken een normatieve probleemstelling te formuleren die ik ook zelf zou kunnen beantwoorden: aan de criteria die ik voor de beantwoording van de probleemstelling zou moeten gebruiken, moest dan - een eis van De Geest die me wel aansprak - een basisnorm ten grondslag liggen. Deze basisnorm kon ik niet, zoals hij suggereerde, funderen in de economische of sociale (hulp)wetenschappen, aangezien mijn kennis op beide gebieden tekortschoot. Een hulpwetenschap op een 'lichtere' manier inzetten - zoals volgens Taekema en Van Klink tot de mogelijkheden behoorde - bijvoorbeeld als inspiratiebron voor de invulling van de basisnorm, zag ik niet zitten, aangezien ik vreesde dat de verantwoording van die keuze datgene waar het me in het onderzoek werkelijk om ging, zou overschaduwen. Wat ik wel kon doen, was de parallel verder uitwerken die Westerman en Wissink tussen het onderwerp en het theoretisch kader van juridisch onderzoek signaleerden.

\subsection{Probleemstelling III}

Mijn derde - en zoals het er nu naar uitziet, laatste - probleemstelling is in feite een geval van oude wijn in nieuwe zakken. Zij luidt hetzelfde als mijn eerste: wat is de reikwijdte van het zelfrealisatierecht en op welke wijze mag de overheid het beperken? De normatieve component vul ik nu op een andere manier in: met hoger recht.

De uitgangspunten die ik in mijn onderzoek hanteer, zijn de volgende. In de eerste plaats is - zoals ik uit mijn verkennende onderzoek al had afgeleid en tijdens de loop van het onderzoek steeds bevestigd heb gezien - de reikwijdte van het zelfrealisatierecht geen vast gegeven. Om verwarring te voorkomen en eenduidige juridische begripsvorming en -ontwikkeling te bevorderen, is het van belang dat daarnaar onderzoek wordt gedaan.

Hoewel op de reikwijdte de vinger niet precies kan worden gelegd, is het ook niet zo dat we volledig in het duister tasten. Zo wordt algemeen aanvaard dat het zelfrealisatierecht samenhangt met het eigendomsrecht: alleen als men grondeigenaar is, kan men een zelfrealisatierecht hebben. Dat is mijn tweede uitgangspunt.

Doordat het met het eigendomsrecht samenhangt, beweegt het zelfrealisatierecht zich noodzakelijkerwijs tussen twee niet realistische, maar denkbare uitersten. Aan de ene kant van het spectrum staat de grondeigenaar die alles mag (niet bouwen, wel bouwen, en zo ja, wat en op welke manier, slopen, zelf zijn samenwerkingspartners kiezen, enzovoort); aan de andere kant staat de grondeigenaar die weliswaar eigenaar is, maar verder niets te zeggen heeft: alle dingen die de eerste grondeigenaar zelf mag beslissen, worden voor hem door de overheid besloten. Het 'werkelijke' zelfrealisatierecht waarbij, afhankelijk van de ruimte- 
lijke doelstellingen van de overheid, het instrumentarium dat voor de verwezenlijking daarvan wordt geformuleerd en de concrete omstandigheden van het geval, nu eens meer waarde wordt gehecht aan de belangen van de grondeigenaar en dan weer aan die van de overheid, beweegt zich daartussen. Dat is mijn derde uitgangspunt.

Mijn proefschrift omvat vier delen en is als volgt opgebouwd. In het eerste deel staan de private, op het eigendomsrecht gebaseerde belangen van particuliere grondeigenaren centraal. Aan de hand van het BW, de Grondwet en het Eerste Protocol bij het EVRM belicht ik de verschillende facetten (beschikken, gebruiken en vruchten trekken) van het eigendomsrecht en geef ik aan op welke wijze deze mogen worden beperkt.

Deel II geeft weer wat de voornaamste ruimtelijke doelstellingen van de overheid vanaf het begin van de twintigste eeuw zijn geweest. De verschuivingen op de grondmarkt komen hierin duidelijk naar voren (eerst had de overheid bijna alle grond in eigendom, later kwamen er steeds meer particuliere grondeigenaren). Ik besteed onder andere aandacht aan de (totstandkoming van) de Woningwet en de WRO, waarin belangrijke instrumenten werden geïntroduceerd om deze doelstellingen te bereiken. Daarbij geef ik - aan de hand van de conclusies van het eerste deel - aan op welke manier deze instrumenten ingrijpen in het eigendomsrecht van private grondeigenaren.

In deel III van het boek komen de wetten waarin het zelfrealisatierecht uitdrukkelijk een rol speelt uitgebreid aan de orde. Het gaat dan om de al eerder genoemde Ow, Wvg en Grex. Ook hier ligt de nadruk op de ruimtelijke doelstellingen van de overheid - maar dan specifiek in de genoemde wetten - en het instrumentarium dat de wetgever heeft ontworpen om tot resultaten te komen, en maak ik een koppeling naar de conclusies van deel I. Daarnaast bezie ik hoe de rechter in conflictsituaties de belangen van de gemeente en die van de grondeigenaar weegt.

Deel IV handelt over de Aanbestedingsrichtlijn. Eisen die op grond van deze Richtlijn aan aanbestedende diensten worden gesteld, kunnen op gespannen voet staan met nationale, wettelijke regelingen en met de invulling die in bepaalde omstandigheden aan het zelfrealisatierecht wordt gegeven.

Op deze manier bezie ik het zelfrealisatierecht op drie niveaus: de denkbare uitersten geven de grenzen aan waarbinnen het recht überhaupt een rol kan spelen. Het kader uit deel I geeft de grenzen van het eigendomsrecht - en dus ook van het zelfrealisatierecht - aan binnen die uitersten. Ook de regels in de Aanbestedingsrichtlijn begrenzen het zelfrealisatierecht. Het gaat om grenzen die door de wet aan het recht worden gesteld; grenzen dus waarbinnen het recht een rol mag spelen. Het derde niveau is het niveau waarop conflicten over de reikwijdte van het recht zich daadwerkelijk afspelen. Bij het beslechten van zo'n conflict moet de rechter rekening houden met de grenzen die door de wet aan het eigendoms- en zelfrealisatierecht zijn gesteld. In de meeste gevallen zal hij binnen die grenzen blijven.

Een ideale invulling van het zelfrealisatierecht of een richting waarin het recht zich zou moeten bewegen, formuleer ik niet, maar dat is, gezien de opzet van mijn onderzoek, ook niet nodig: alle facetten van het eigendoms- en zelfrealisatierecht (beschikken, gebruiken en vruchten trekken) worden bezien in het licht van alle 
instrumenten die de overheid ter beschikking staan om haar ruimtelijke doelstellingen te realiseren. Dissonanten vallen op deze manier dus altijd meteen op. Of daaraan iets moet gebeuren, en zo ja, op welke manier, is een politieke afweging die ik als onderzoeker niet kan maken. Wel ga ik in de conclusie in op verschillende standpunten die in het politieke debat over het zelfrealisatierecht zijn ingenomen. Zo laat ik zien dat de stelling van de minister dat afschaffing van het zelfrealisatierecht in strijd zou zijn met artikel 1 EP EVRM, ${ }^{15}$ niet in alle gevallen waar is.

\section{Ten slotte}

Het volgen van het debat over de aard van de rechtswetenschap in - met name het NJB heeft me in de eerste plaats geholpen mijn probleemstelling op een werkbare manier te formuleren. Daarnaast heeft het me ook aangezet tot het beter en gestructureerder nadenken over de vraag waar mijn collega-onderzoekers en ik nu eigenlijk mee bezig zijn: we duiden begrippen aan de hand van bronnen volgens een bepaalde - meestal interpretatieve - methode.

Het duiden van begrippen gebeurt natuurlijk ook door de wetgever en de rechter. Er is echter wel een verschil: als de wetgever of de rechter aan een begrip een bepaalde betekenis toekent, staat die betekenis - in ieder geval voorlopig, dat wil zeggen totdat aan het begrip door de wetgever of de rechter een nieuwe betekenis wordt gegeven - vast. Wanneer de wetgever of de rechter stelt dat onder het zelfrealisatierecht moet worden verstaan - ik noem maar wat - 'het recht van een private grondeigenaar om voor eigen rekening en risico en geheel naar eigen inzicht de nieuwe bestemming op zijn perceel te realiseren', dan is dat zo. Ik kan als wetenschapper precies dezelfde bewering doen, maar die heeft dan noodzakelijkerwijs een normatieve lading ('onder het zelfrealisatierecht zou moeten worden verstaan...') en is daarom niet gezaghebbend. Tenminste: niet zolang de wetgever of de rechter het begrip niet al aan zich heeft getrokken. Wanneer dat wel is gebeurd, is de vraag 'wat moet worden verstaan onder het zelfrealisatierecht?' echter geen normatieve vraag meer, maar een feitelijke.

Voor het beantwoorden van feitelijke vragen zijn primair juridische bronnen (de wet en de rechtspraak) dus geschikt. Kunnen aan de hand van die bronnen nu ook normatieve vragen worden beantwoord? Ik zou deze vraag instemmend beantwoorden als het gaat om een normatieve vraag die ziet op nationaal recht in het licht van in ons land geldend, hoger recht (bijvoorbeeld EU-recht of volkenrecht en de daaruit voortvloeiende jurisprudentie). De vraag 'is de zojuist gegeven definitie van het zelfrealisatierecht houdbaar in het licht van artikel 1 EP EVRM?' lijkt mij een voorbeeld van een normatieve vraag die aan de hand van louter primair juridische bronnen kan worden beantwoord. Met enige voorzichtigheid - mijn opvattingen op dit punt zijn nog niet uitgekristalliseerd - zou ik nu beweren dat dit ook de enige vraagstelling is waarvoor dit geldt; andere normatieve uitspraken dan die over de compatibiliteit van nationaal recht met hoger, internatio- 
naal recht, kunnen aan de hand van primair juridische bronnen misschien wel niet worden gedaan.

Voor het beantwoorden van andere normatieve vragen heeft de rechtswetenschapper dus méér dan alleen primair juridische bronnen nodig en vaak zelfs - in de terminologie van Taekema en Van Klink - een 'hulpwetenschap'. Dat deze hulpwetenschap - zoals De Geest betoogt - steeds de economische wetenschap zou zijn, onderschrijf ik niet. Ook de filosofie, de geschiedenis, de ethiek, de psychologie, de politicologie en de wiskunde kunnen volgens mij - uiteraard afhankelijk van de formulering van de probleemstelling - als hulpwetenschap dienen. Hierbij moet de onderzoeker zich er wel rekenschap van geven dat binnen deze hulpwetenschap wellicht andere methoden worden gehanteerd: juristen interpreteren vooral teksten, maar zijn doorgaans niet bekend met het verzamelen en verwerken van statistische gegevens of met het operationaliseren van wiskundige of economische formules. Zelfs bij hulpwetenschappen die óók een interpretatieve methode hanteren - bijvoorbeeld de filosofie - kan soms lastig aansluiting worden gezocht, aangezien juristen niet steeds bekend zijn met het begrippenkader dat binnen die wetenschap wordt gehanteerd. Juridisch onderzoekers moeten dus hoe dan ook goed zijn ingevoerd in de hulpwetenschap die zij voor het beantwoorden van hun probleemstelling gebruiken.

Het - eventueel met een hulpwetenschap als inspiratiebron, maar toch min of meer arbitrair - uitgaan van een bepaalde invulling voor een beginsel als toetsingscriterium spraken me, uit vrees dat de verantwoording van de keuze voor die invulling de onderzoeksresultaten zou overschaduwen, niet zo aan. Het gebruik van een hulpwetenschap in een door Taekema en Van Klink als 'zwaarder' omschreven vorm - bijvoorbeeld op interdisciplinaire wijze, in welk geval ik mijn toetsingscriteria aan de hand van economische of sociaalwetenschappelijke begrippen en methoden zou hebben ingevuld - heb ik in mijn onderzoek niet aangedurfd: mijn kennis over deze wetenschappen schiet vooralsnog tekort om er criteria ter beantwoording van mijn probleemstelling aan op te hangen.

Ik ben uiteraard niet de enige voor wie dat geldt: veel juristen hebben te weinig kennis van andere wetenschapsgebieden om interdisciplinair onderzoek te doen. Tegelijkertijd denk ik dat normatieve probleemstellingen lang niet altijd aan de hand van louter juridische criteria kunnen worden beantwoord, en dat het invullen van criteria 'op eigen houtje' of aan de hand van een hulpwetenschap die als inspiratiebron wordt gebruikt, in veel gevallen niet tot de meest wenselijke benaderingen behoort. Een voor de hand liggende vraag in dit verband is of dat 'erg' is. ${ }^{16}$ Wordt hierdoor afbreuk gedaan aan de mate 'wetenschappelijkheid' van de rechtswetenschap? Ik zou menen van niet. Wel lijkt me van belang dat juridisch onderzoekers zich van deze omstandigheden voldoende rekenschap geven bij het formuleren van een probleemstelling en toetsingscriteria: zij zullen zich steeds moeten afvragen wat voor soort vraag ze willen beantwoorden, welke toetsingscriteria ze kunnen formuleren ter beantwoording van die vraag en hoe ze die toetsingscriteria kunnen operationaliseren. Dit vergt veel van de onderzoeksvaardigheden van juridisch wetenschappers. Het vergt daarnaast - en dat lijkt mij 
minstens zo belangrijk - veel van hun creativiteit. Want hoewel onderzoekers uiteraard steeds de formele vereisten die aan wetenschapsbeoefening worden gesteld scherp in het oog moeten houden, is er mijns inziens een ander belangrijk punt dat zij nooit uit het oog moeten verliezen: wetenschap is - binnen die formele vereisten - vooral ook een kwestie van originaliteit en creativiteit. ${ }^{17}$ Het proces van het zoeken naar een goede probleemstelling, het aftasten van mogelijke toetsingscriteria en het omarmen en verwerpen van verschillende mogelijkheden en benaderingswijzen, helpt bij het stimuleren van die creativiteit en zou ik iedere onderzoeker dan ook van harte toewensen.

\section{Literatuur}

\section{Bregman \& Lubach 2000}

A.G. Bregman \& D.A. Lubach, Modernisering gemeentelijk grondbeleidsinstrumentarium, Deventer: Kluwer 2000.

\section{De Bruin 2009}

B. de Bruin, 'Over de wetenschappelijkheid van de rechtswetenschap', $R \& R$ 2009-3, p. 236-244.

\section{Van der Burg 2008}

W. van der Burg, 'Creativiteit in de rechtswetenschap: over interdisciplinariteit als heuristiek', NJB 2008, p. 2742-2746.

Burkens e.a. 2006

M.C. Burkens e.a., Beginselen van de democratische rechtsstaat, Alphen aan den Rijn: Kluwer 2006, p. 15-26.

De Geest 2004

G.G.A. de Geest, 'Hoe maken we van de rechtswetenschap een volwaardige wetenschap?', NJB 2004, p. 58-66.

\section{Kortmann 2005}

C.A.J.M. Kortmann, Constitutioneel recht, Deventer: Kluwer 2005.

\section{Van Manen 2008}

N.F. van Manen, 'Wat de rechtswetenschap (niet) zo bijzonder maakt', NJB 2008, p. 1927-1930.

Van Ommeren \& Zijlstra 2003

F.J. van Ommeren \& S.E. Zijlstra (red.), De rechtsstaat als toetsingskader, Den Haag: Boom Juridische uitgevers 2003.

\section{Scheltema 1989}

M. Scheltema, 'De rechtsstaat', in: J.W.M. Engels e.a., De rechtsstaat herdacht, Zwolle: Tjeenk Willink 1989, p. 16-22.

\section{Schlössels \& Zijlstra 2010}

R.J.N. Schlössels \& S.E. Zijlstra, Bestuursrecht in de sociale rechtsstaat, Deventer: Kluwer 2010.

\section{Sluysmans \& Bronneman 2006}

J.A.M.A Sluysmans \& M. Bronneman, 'Zelfrealisatie onder vuur', Agrarisch recht 2006-6, p. 288-306. 


\section{Smits 2009}

J.M. Smits, Omstreden rechtswetenschap: over de aard, methode en organisatie van de juridische discipline, Den Haag: Boom Juridische uitgevers 2009.

\section{Spijkerboer 2010}

T.P. Spijkerboer, 'Voor een fundamentele rechtswetenschap', NJB 2010, p. 604-610.

\section{Stolker 2003}

C.J.J.M. Stolker, '“Ja, geléérd zijn jullie wel!' Over de status van de rechtswetenschap', NJB 2003, p. 766-778.

\section{Taekema \& Van Klink 2009}

H.S. Taekema \& B.M.J. van Klink, 'Dwarsverbanden: interdisciplinair onderzoek in de rechtswetenschap', NJB 2009, p. 2559-2567.

\section{Tijssen 2009}

H.E.B. Tijssen, De juridische dissertatie onder de loep. De verantwoording van methodologische keuzes in juridische dissertaties, Den Haag: Boom Juridische uitgevers 2009.

\section{De Vries 1989}

J. de Vries, Grondpolitiek en kabinetscrises, Den Haag: VUGA-uitgeverij 1989.

\section{Wendt 2009}

J.A.I. Wendt, 'De opgekomen methodenvrees in het rechtswetenschappelijk debat in Nederland. Een voorstel', NJB 2009, p. 782-789.

\section{Westerman 2007}

P. Westerman, 'Doelregulering in de rechtswetenschap', NJB 2007, p. 1673-1674.

\section{Westerman \& Wissink 2008}

P. Westerman \& M. Wissink, 'Rechtsgeleerdheid als rechtswetenschap', NJB 2008, p. 503-507.

Wetenschappelijke Raad voor het Regeringsbeleid 2000

WRR, Het borgen van publiek belang, Den Haag: WRR 2000, nr. 56.

\section{Zijlstra 2008}

S.E. Zijlstra, 'De grenzen van de overheid', in: Privaat bestuur?, preadviezen VAR-reeks 140, Den Haag: Boom Juridische uitgevers 2008.

\section{Zijlstra 2010}

S.E. Zijlstra, 'Democratische rechtsstaat', in: R.J.N. Schlössels \& S.E. Zijlstra, Bestuursrecht in de sociale rechtsstaat, Deventer: Kluwer 2010.

\section{Van Zundert 1980}

J.W. van Zundert, Overheidsbestuur en grondeigendom, Alphen aan den Rijn: Samsom 1980. 